Original Article

\title{
Status Gizi, Asupan Zat Gizi Makro dan Kaitannya dengan Kadar HbA1c PADA Pasien Diabetes Melitus Tipe 2
}

\section{Nutritional Status, Macronutrients Intake and its associated with HbAlc Levels in Type 2 Diabetes Mellitus Patients}

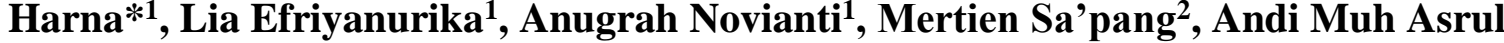 \\ Irawan $^{3}$ \\ 1Program Studi Gizi Fakultas Ilmu-Ilmu Kesehatan Universitas Esa Unggul, Indonesia \\ ${ }^{2}$ Program Studi Profesi Dietisien Fakultas Ilmu-Ilmu Kesehatan Universitas Esa Unggul, Indonesia \\ ${ }^{3}$ Program Studi Gizi Fakultas Sains dan Teknologi Universitas Al Azhar Indonesia, asrul.irawan@uai.ac.id \\ (*harna@esaunggul.ac.id, 081289903103)
}

\begin{abstract}
ABSTRAK
Diabetes Mellitus (DM) adalah penyakit menahun degeneratif yang ditandai dengan kenaikan glukosa di dalam darah yang disebabkan oleh kerusakan kelenjar pankreas sebagai penghasil hormon insulin sehingga terjadi gangguan metabolisme karbohidrat, lemak, dan protein yang dapat menimbulkan berbagai keluhan serta komplikas. Tujuan penelitian ini yaitu menganalisis status gizi dan asupan zat gizi makro serta hubungannya dengan kadar HbA1c pada pasien Diabetes Mellitus. Metode penelitian yaitu menggunakan desain penelitian cross-sectional. Responden penelitian ini yaitu pasien Diabetes Melitus tipe II yang berobat jalan di Rumah Sakit Siloam Hospitals Lippo Village selama periode penelitian yaitu pada bulan Januari 2019 sebanyak 70 responden. Data dianalisis dengan menggunakan uji Kolerasi Spearman. Hasil penelitian menunjukkan bahwa kadar HbA1C responden sebanyak $81,4 \%$ tidak terkontrol. Sebanyak $87,1 \%$ responden masuk dalam kategori status gizi lebih. Hasil penelitian menunjukkan bahwa tidak ada hubungan yang signifikan antara status gizi dan kadar $\mathrm{HbA} 1 \mathrm{c}$ pada responden $(\mathrm{p}>0.05)$. Ada hubungan yang signifikan antara asupan karbohidrat, lemak, dan serat dengan kadar $\mathrm{HbA} 1 \mathrm{c}(\mathrm{p}<0.05)$, dengan median asupan karbohidrat 254,25 gram, asupan lemak 96.09 gram dan serat 19,1 gram. Sedangkan untuk asupan protein tidak berhubungan signifikan dengan kadar $\mathrm{HbA1c}(\mathrm{p}>0.05)$. Kesimpulan pada penelitian ini yaitu status gizi dan asupan zat gizi makro berhubungan dengan kadar HbA1c pada pasien Diabetes Melitus di Siloam Hospitals Lippo Village.
\end{abstract}

\section{Kata kunci : Diabetes melitus, Status gizi, Karbohidrat, Serat, Lemak}

\section{ABSTRACT}

Diabetes Mellitus (DM) is a chronic degenerative disease characterized by an increase in blood sugar caused by damage to the pancreas gland as a producer of the hormone insulin, causing disruption of carbohydrate, fat and protein metabolism which can cause various complaints and complications. The purpose of this study was to analyze the nutritional status and intake of macronutrients and it's correlations with HbAlc levels in Diabetes Mellitus patients. The research method was using a crosssectional research design. Respondents of this study were patients with Type II Diabetes Mellitus who had outpatient treatment at Siloam Hospitals Lippo Village during the study period, namely in January 2019, as many as 70 respondents. The results showed that there was no significant relationship between nutritional status and HbAlc levels in respondents, with a p-value $=0.882(p>0.05)$. There was a significant relationship between carbohydrate, fat, and fiber intake with HbAlc levels ( $p<0.05)$, while protein intake was not significantly associated with HbAlc levels ( $p>0.05$ ). The conclusion of this study were that nutritional status and macro nutrient intake are related to HbAlc levels in Diabetes Mellitus patients at Siloam Hospitals Lippo Village.

Keywords : Diabetes mellitus, nutritional status, carbohydrate, fiber, fat

\section{https://doi.org/10.33860/jik.v15i4.806}




\section{PENDAHULUAN}

Diabetes melitus (DM) merupakan suatu kelompok penyakit metabolik dengan karakteristik terjadinya peningkatan kadar gula darah yang tinggi atau hiperglikemia yang diakibatkan oleh gangguan sekresi insulin, kerja insulin atau keduanya ${ }^{(1)}$. Diabetes Mellitus (DM) adalah penyakit menahun degeneratif yang ditandai dengan kenaikan gula di dalam darah yang disebabkan oleh kerusakan kelenjar pankreas sebagai penghasil hormon insulin sehingga terjadi gangguan metabolisme karbohidrat, lemak, dan protein yang dapat menimbulkan berbagai keluhan serta komplikasi ${ }^{(2),(3)}$.

Diabetes telah menjadi salah satu masalah kesehatan secara global dan menurut estimasi International Diabetes Federation (IDF) tahun 2017, lebih dari 425 juta orang di seluruh dunia mengalami DM dan sekitar setengah dari 4 juta orang yang meninggal akibat diabetes berusia di bawah 60 tahun ${ }^{(4)}$. Prediksi WHO terkait penderita DM bahwa terjadi di Indonesia dari 8,4 juta pada tahun 2000 menjadi sekitar 21,3 juta pada tahun 2030. Laporan ini menunjukkan adanya peningkatan jumlah penyandang DM sebanyak 2-3 kali lipat pada tahun $2035^{(1)}$. Sedangkan International Diabetes Federation (IDF) memprediksi adanya kenaikan jumlah penyandang DM di Indonesia dari 6,2 juta pada tahun 2017 menjadi 7,4 juta pada tahun $2045^{(4)}$. Berdasarkan riskesdas tahun 2018, prevalensi DM di Indonesia berdasarkan wawancara pada umur $\geq$ 15 tahun dalah $1.8 \%{ }^{(5)}$.

The American Diabetes Association (ADA) merekomendasikan beberapa parameter yang dapat digunakan untuk menilai keberhasilan penatalaksanaan diabetes, salah satunya yaitu kadar HbA1c. Kadar HbA1c yang diharapkan yaitu $<7 \mathrm{mg} / \mathrm{dL}{ }^{(6)}$. HbAlc merupakan ikatan molekul glukosa pada hemoglobin secara non-enzimatik melalui proses glikasi post translasi. Hemoglobin yang terglikasi dalam beberapa asam amino $\mathrm{HbA}$ meliputi HbA1a, HbA1b dan HbA1c. Status HbA1c merupakan komponen terpenting dari glikasi hemoglobin untuk menilai Diabetes mellitus. HbA1c digunakan sebagai patokan utama untuk pengendalian penyakit DM karena dapat mengambarkan kadar gula darah dalam rentang 1-3 bulan, hal itu dikarenakan usia sel darah merah yang terikat oleh molekul glukosa adalah 120 hari $^{(7)}$.

$$
\text { Status Gizi menggambarkan }
$$

keseimbangan antara zat gizi yang kita konsumsi dan zat gizi yang digunakan oleh tubuh. Kondisi status gizi lebih atau obesitas merupakan salah satu faktor resiko dari kejadian penyakit degeneratif ${ }^{(8)}$. Obesitas akan terjadi peningkatan produksi resistin yang akan mendorong resistensi insulin dengan mengganggu kerja insulin. Sebaliknya adiponektin, adipokin lainnya akan meningkatkan sensitivitas terhadap insulin dengan meningkatkan efek insulin, tetapi pada obesitas terjadi penurunan hormon ini. Selain itu asam lemak yang dikeluarkan dari jaringan lemak dapat menumpuk abnormal di otot dan mengganggu kerja insulin otot. Pengendalian berat badan pada penderita yang obesitas dapat memperbaiki kadar glikemik jangka pendek dan mempunyai potensi meningkatkan kontrol metabolik jangka panjang ${ }^{(9)}$.

Penatalaksanaan Diabetes Melitus yang tidak tepat menyebabkan glukosa darah pasien menjadi sulit terkontrol dan dapat mengakibatkan berbagai komplikasi, seperti neuropati diabetik, nefropati diabetik, stroke, kebutaan, dan ulkus diabetik yang berpengaruh terhadap kualitas hidup pasien (10). Tujuan utama untuk pengendalian penyakit diabetes melitus adalah menghilangkan gejala-gejala DM dan menopang rasa nyaman dan sehat. Jangka panjangnya adalah mencegah komponen yang berhubungan dengan kadar gula darah yang tinggi ${ }^{(11)}$.

Pola makan yang baik merupakan bagian penting dari penatalaksanaan diabetes. Diet yang baik akan mengurangi beban kerja insulin dengan mengoptimalisasikan pekerjaan insulin mengubah glukosa menjadi glikogen. Keberhasilan terapi ini melibatkan dokter, perawat, ahli gizi, pasien itu sendiri dan keluarganya ${ }^{(12)}$. Penderita diabetes dianjurkan untuk konsumsi serat, konsumsi serat yang diajurkan minimal $25 \mathrm{~g}$ per hari. Serat akan membantu menghambat penyerapan lemak, makanan berserat yang tidak dapat dicerna oleh tubuh juga dapat membantu mengatasi rasa lapar yang dirasakan penderita Diabetes Melitus tanpa risiko masukan kalori yang berlebih hal ini secara tidak langsung akan menurunkan kadar glukosa darah. Selain itu makanan sumber serat seperti sayur dan buahbuahan segar umumnya kaya akan vitamin dan mineral yang baik bagi pasien Diabetes Melitus (6),(13).

$$
\text { Beberapa penelitian telah }
$$
membuktikan bahwa ada hubungan antara 
status gizi dan asupan zat gizi makro, namun terdapat hasil yang tidak konsisten dengan hasil penelitian lain yang mengatakan bahwa tidak terdapat hubungan. Berdasarkan permasalahan diatas, penulis tertarik untuk melakukan penelitian ini yang bertujuan menganalisis hubungan status gizi dan asupan zat gizi makro dengan kadar HbAlc pada pasien Diabetes Melitus Tipe II di Siloam Hospitals Lippo Village.

\section{METODE PENELITIAN}

Penelitian yang dilakukan menggunakan desain penelitian cross-sectional. Responden penelitian ini yaitu pasien Diabetes Melitus tipe II yang berobat jalan di Rumah Sakit Siloam Hospitals Lippo Village selama periode penelitian yaitu pada bulan Januari 2019. Penelitian ini telah mendapatkan ijin dan persetujuan dari Komisi Etik Universitas Esa Unggul dengan Nomor. 0022-19.012/DPKEKEP/FINAL-EA/UEU/I/2019.

Sampel yang diambil berdasarkan kriteria eksklusi dan inklusi yaitu pasien yang terdiagnosis Diabetes Melitus Tipe II, dilakukan pengecekan kadar HbA1c, mendapatkan transfusi insulin, tidak memiliki gangguan ginjal, anemia dan tidak menjalankan transfusi darah. Sampel yang diambil yaitu sebesar 70 responden dan responden yang bersedia diteliti mendatangani inform consent.

Variabel dalam penelitian ini yaitu status gizi dan asupan zat gizi makro dan kadar HbA1c. Data yang dikumpulkan pada penelitian ini yaitu data primer dan data sekunder. Data primer meliputi asupan zat gizi makro yang diperoleh menggunakan Semi Food Frequency Questionnaire dan data sekunder yang diambil dari data rekam medis meliputi berat badan, tinggi badan serta kadar $\mathrm{HbAlc}$ yang di lakukan pemeriksaan maksimal 3 bulan terakhir.

Analisis data yang dilakukan yaitu analisis univariat dan analisis bivariat. Analisis univariat meliputi data status gizi, pengetahuan tentang diabetes melitus dan kadar HbAlc. Analisis bivariat yaitu untuk menganalisa adanya hubungan antara variable independent (status gizi dan asupan zat gizi makro) dan variable dependent (kadar HbA1c). Data dianalisis dengan menggunakan uji Kolerasi Spearman.

\section{HASIL}

\section{Karakteristik Responden}

Hasil analisis yang dilakukan pada pasien rawat jalan yang terdiagnosis diabetes mellitus di Rumah Sakit Siloam Hospitals Lippo Village sebanyak 70 responden sebanyak 1 orang $(1,4 \%)$ memiliki status gizi kurang $\left(<18,5 \mathrm{~kg} / \mathrm{m}^{2}\right)$, sebanyak 8 orang $(11,4 \%)$ memiliki status gizi normal $(18,5-22,9 \mathrm{~kg} / \mathrm{m} 2)$ dan sebanyak 61 orang $(87,1 \%)$ memiliki status gizi lebih $(\geq 23 \mathrm{~kg} / \mathrm{m} 2)$. Median IMT pada indeks massa tubuh responden yaitu sebesar $25,8 \mathrm{~kg} / \mathrm{m} 2 \pm \mathrm{SE} 0,55 \mathrm{~kg} / \mathrm{m}^{2}$, dengan indeks massa tubuh terendah yaitu $16,89 \mathrm{~kg} / \mathrm{m} 2$ serta yang tertinggi yaitu $52,29 \mathrm{~kg} / \mathrm{m}^{2}$.

Tabel 1 Distribusi Frekuensi Status Gizi dan kadar HbA1c Responden

\begin{tabular}{|c|c|c|}
\hline \multicolumn{3}{|c|}{ Kadar HbAlc Responden } \\
\hline Variabel & $\mathrm{n}$ & $\%$ \\
\hline \multicolumn{3}{|l|}{ Status Gizi } \\
\hline Kurang $(<18,5 \mathrm{~kg} / \mathrm{m} 2)$ & 1 & $1,4 \%$ \\
\hline Normal $(18,5-22,9 \mathrm{~kg} / \mathrm{m} 2)$ & 8 & $11,4 \%$ \\
\hline Lebih $(\geq 23 \mathrm{~kg} / \mathrm{m} 2)$ & 61 & $87,1 \%$ \\
\hline \multicolumn{3}{|l|}{ Kadar HbA1C } \\
\hline Terkontrol $(<7 \%)$ & 13 & $18,6 \%$ \\
\hline Tidak Terkontrol $(\geq 7 \%)$ & 57 & $81,4 \%$ \\
\hline
\end{tabular}

Konsumsi zat gizi makro yang terdiri dari karbohidrat, protein, lemak dan serat didapatkan dari hasil wawancara dengan pasien menggunakan metode Semi Food Frequency Questionnaire selama konsumsi 1 bulan terakhir.

Berdasarkan tabel 2 menunjukkan bahwa dari 70 pasien rawat jalan median konsumsi karbohidrat sebesar 254,25 \pm SE 16,77 dan konsumsi karbohidrat terendah yaitu sebesar 105,30 gram serta yang tertinggi yaitu 689,42 gram. Konsumsi protein dengan median sebesar 96,09 \pm SE 4,48 dan konsumsi protein terendah yaitu sebesar 63,90gram serta yang tertinggi yaitu 343,37 gram. Dari 70 responden konsumsi lemak dengan median 119,73 \pm SE 4,32 dan konsumsi lemak terendah yaitu sebesar 54,87gram serta yang tertinggi yaitu 217,50 gram. Responden mengonsumsi serat dengan median 19,1 \pm SE 0,78 dan konsumsi serat terendah yaitu sebesar 8,56 gram serta yang tertinggi yaitu 39,8 gram.

\section{Hubungan Status Gizi dan Asupan Zat Gizi Makro terhadap Kadar HbA1C}

Beradasarkan Tabel 3 menunjukkan bahwa nilai $\mathrm{p}$-value $=0,882(\mathrm{p}>0,05)$, yang 
artinya tidak ada hubungan yang signifikan antara status gizi dan kadar $\mathrm{HbA1c}$ pada responden, dengan nilai $(\mathrm{r})=0,018$ yang artinya variable status gizi dan kadar $\mathrm{HbA} 1 \mathrm{c}$ mempunyai kekuatan hubungan yang lemah dan bernilai positif yang artinya semakin tinggi status gizi maka semakin tinggi pula kadar HbA1c pada responden

Tabel 2 Distribusi Frekuensi Konsumsi Zat Gizi Makro (Karbohidrat, Protein, Lemak, Serat) Responden

\begin{tabular}{cccc}
\hline Variabel & median & SE & $\min -\max$ \\
\hline Karbohidrat & 254,25 & 16,77 & $105,30-689,42$ \\
Protein & 96,09 & 4,48 & $63,9-343,37$ \\
Lemak & 119,73 & 4,32 & $54,87-217,50$ \\
Serat & 19,1 & 0,78 & $8,56-39,8$ \\
\hline
\end{tabular}

Tabel 3 Hubungan Status Gizi dan Asupan Zat Gizi Makro dengan Kadar HbA1c

\begin{tabular}{lcc}
\hline Variabel & \multicolumn{2}{c}{ Kadar HbA1c } \\
\cline { 2 - 3 } & $\mathbf{r}$ & p-value \\
\hline Indeks Massa Tubuh & 0,018 & 0,882 \\
Asupan Karbohidrat & 0,768 & 0,001 \\
Asupan Protein & 0,213 & 0,077 \\
Asupan Lemak & 0,494 & 0,001 \\
Asupan Serat & $-0,475$ & 0.001 \\
\hline
\end{tabular}

Beradasarkan data pada Tabel 3 diperoleh dengan menggunakan uji Spearman's rho Correlation yaitu nilai $p$-value $=0,001(\mathrm{p}$ $<0,05)$, yang artinya ada hubungan yang signifikan antara konsumsi karbohidrat dan kadar HbA1c, dengan nilai $(r)=0,768$ yang artinya variable konsumsi karbohidrat dan kadar HbA1c mempunyai kekuatan hubungan yang kuat dan bernilai positif yang artinya semakin tinggi konsumsi karbohidrat semakin tinggi pula kadar $\mathrm{HbA1c}$ responden.

\section{PEMBAHASAN}

Hasil penelitian menunjukkan bahwa tidak terdapat hubungan yang signifikan antara indeks massa tubuh dan kadar $\mathrm{HbA1c}$ mempunyai, dengan nilai kekuatan hubungan yang lemah. Hal ini disebabkan karena responden yang memiliki status gizi normal atau kurang merupakan pasien diabetes mellitus yang tidak terkontrol. Dari hasil penelitian yang dilakukan di dapat beberapa responden mengalami kegemukan sebelum menderita diabetes mellitus, tetapi setelah menderita diabetes mellitus berat badannya cenderung menurun. Penelitian sebelumnya menjelaskan bahwa kadar HbAlc yang tinggi pada kelompok pasien dengan IMT $<25$ mengindikasikan peningkatan keparahan penyakit ${ }^{(14)}$.
Kadar HbA1c yang tinggi pada responden yang memiliki IMT normal dan kurang dapat terjadi karena pada awal terjadi diabetes mellitus berat badan akan meningkat tetap lama kelaman otot tidak mendapatkan cukup glukosa untuk tumbuh dan untuk menjadikannya energi, sehingga otot dan lemak dipecah untuk memenuhi kebutuhan energi. Keadaan ini diperburuk juga oleh adanya komplikasi yang timbul ${ }^{(15)}$. Selain itu, tubuh selalu berupaya mengatur gula darah agar tidak melebihi $180 \mathrm{mg} / \mathrm{dl}$, dengan cara gula yang tinggi akan dibuang melalui ginjal bersamaan dengan urin. Gula memiliki nilai osmolaritas yang tinggi sehingga membuat air ikut keluar besamaan dengan air, hal ini dapat menyebabkan penurunan berat badan karena jumlah cairan sering kali keluar melalui urin ${ }^{(16)}$.

Hasil penelitian menunjukkan bahwa tidak terdapat hubungan yang signifikan antara obesitas menurut IMT dengan kadar HbA1c juga dapat terjadi karena faktor lain, seperti adanya obesitas sentral. Obesitas yang diukur dengan indeks massa tubuh tidak sensitif dalam menggambarkan gangguan metabolik yang terjadi. Obesitas sentral yang digambarkan oleh lingkar pinggang lebih sensitif dalam memprediksi gangguan metabolic ${ }^{(17)}$. Semakin banyak jaringan lemak pada tubuh maka tubuh semakin resisten terhadap kerja insulin, terutama bila lemak tubuh atau kelebihan berat badan terkumpul di daerah sentral ${ }^{(18)}$. 
Hasil ini dikuatkan dengan penelitian yang lakukan Utomo pada tahun 2015 juga membuktikan tidak terdapat hubungan yang bermakna antara kadar HbA1c dengan indeks massa tubuh ${ }^{(19)}$. Hal ini juga di buktikan oleh Permatasari tahun 2015 penelitian yang menunjukkan hubungan status gizi dengan pengontrolan gula darah yang dinilai dari kadar HbA1C secara statistik tidak signifikan ${ }^{(20)}$.

Penyakit diabetes melitus sangat erat kaitannya dengan asupan makanan. Asupan makanan seperti karbohidrat, protein, lemak, dan energi yang berlebihan dapat menjadi faktor resiko awal kejadian diabetes mellitus. Semakin berlebihan asupan makanan maka semakin besar pula kemungkinan akan menyebabkan diabetes melitus (21),(22). Konsumsi karbohidrat, protein, lemak dan serat didapatkan dari hasil Semi Food Frequency Questionnaire satu bulan terakhir. Sumber karbohidrat meliputi bihun, biscuit, misoa, mie, spaghetti, macaroni, beras ketan hitam, beras ketan putih, havermout, jagung manis, talas, ubi, roti, singkong, kentang, nasi merah, nasi hitam, nasi putih, tepung berasa, tepung jagung, tepung sagu, tepung terigu, kecap, gula aren, gula pasir, madu

Sumber protein hewani yaitu ayam, ikan, ikan asin, daging sapi, daging babi, daging kambing cumi, kerang, udang, hati ayam, hati sapi, babat, ample, bebek, telur dan telur asin. Sumber protein nabati meliputi kacang bogor, kacang hijau, kacang polong, kacang kedelai, kacang merah, kacang mete, kacang tanah, kembang tahu, tofu, tempe dan tahu. Sumber serat yaitu dari sayur dan buah, seperti bayam, buncis, brokoli, daun singkong, jagung manis, genjer, kalian, kangkung, kapri, kacang panjang, ketimun, kembang kol, kol, labu siam, labu air, lobak, pare, sawi putih, sawi hijau, toge, tomat, wortel, dan terong, sedangkan buah-buahan seperti alpukat, apel, pear, melon, anggur, belimbing, bangkuang, duku, durian, jambu biji, jambua air, jeruk, klengkeng, kiwi, mangga, nangka, nanas, papaya, pisang, rambutan, semangka, salak, srikaya, sawo dan sirsak. Sumber lemak yaitu keju, margarin, mentega, minyak, coklat dan santan. Minuman kemasan, susu, kopi juga masuk kedalam pertanyaan Semi Food Frequency Questionnaire.

Berdasarkan hasil penelitian yang dilakukan pada pasien rawat jalan diperoleh konsumsi karbohidrat terendah yaitu sebesar 105,30 gram serta yang tertinggi yaitu 689,42 gram. Dari hasil wawancara yang dilakukan didapatkan hasil sumber karbohidrat yang sering dikonsumsi oleh responden yaitu seperti bihun, biskuit, roti, kopi instan, tepung terigu dan gula pengganti.

Hasil penelitian menunjukkan bahwa ada hubungan antara konsumsi karbohidrat dan kadar HbA1c. Hasil uji kolerasi menunjukkan bahwa nilai (r) sebesar 0,768 yang artinya variable konsumsi karbohidrat dan kadar HbA1c mempunyai kekuatan hubungan yang kuat dan bernilai positif yang artinya semakin tinggi konsumsi karbohidrat semakin tinggi pula kadar $\mathrm{HbA} 1 \mathrm{c}$ responden.

Konsumsi karbohidrat $>65 \%$ dari kebutuhan mengakibatkan kadar HbA1c tinggi, karena penyandang DM tipe 2 memiliki kekurangan resptor insulin sehingga menyebabkan rendahnya jumlah glukosa yang masuk kedalam sel dan rendahnya laju oksidasi glikogenesis untuk merubah glukosa menjadi glikogen yang akan disimpan di hati dan otot sebagai cadangan energi. Tingginya asupan karbohidrat dan rendahnya resptor insulin menyebabkan glukosa yang dihasilkan dari metabolisme karbohidrat yang dikonsumsi dalam jumlah yang melebihi kebutuhan semakin meningkat di pembuluh darah dan tidak dapat dikendalikan dalam batas normal (21),(23).

Dari hasil wawancara yang dilakukan didapatkan hasil sumber protein yang sering dikonsumsi oleh responden yaitu sumber protein hewani seperti ayam, ikan, dan telur, sedangkan sumber protein nabati seperti tahu, tempe dan kacanng tanah. Pada penelitian ini menunjukkan tidak ada kolerasi antara asupan protein dan kadar HbA1c. Asupan protein bagi penyandang diabetes sama dengan masyarakat umumnya dan biasanya tidak melebihi $20 \%$ dari asupan energi total. Kualitas sumber protein yang baik adalah sumber protein yang mengandung asam-asam amino esensial yang lengkap yakni mencakup sembilan jenis asam amino esensial. Diet tinggi protein tidak direkomendasikan sebagai metode untuk menurunkan berat badan pada penderita DM, karena dampak jangka panjang dari asupan protein melebihi $20 \%$ dari kalori total harian masih belum diketahui secara pasti. Protein juga dapat membantu mengontrol faktor-faktor yang berhubungan dengan sindrom metabolik glukosa darah (24)(25). Tidak adanya korelasi antara asupan protein dengan kontrol kadar gula darah kemungkinan disebabkan oleh fungsi 
utama protein adalah untuk pertumbuhan dan mengganti sel-sel yang rusak. Protein akan digunakan sebagai sumber energi apabila ketersediaan energi dari sumber lain yaitu karbohidrat dan lemak tidak mencukupi melalui proses glikoneogenesis ${ }^{(2)}$.

Asupan protein hewani yang lebih tinggi seperti daging merah dan olahan telah dikaitkan dengan risiko diabetes mellitus, sementara asupan sumber protein nabati, seperti kacangkacangan, kacang-kacangan dan makanan kedelai, telah dikaitkan dengan risiko diabetes tipe 2 yang jauh lebih rendah ${ }^{(26)}$.

Hasil penelitian menunjukkan bahwa konsumsi lemak terendah yaitu sebesar 54,87 gram serta yang tertinggi yaitu 217,50 gram. Hasil uji statistik antara konsumsi lemak dan kadar HbA1c terdapat hubungan yang signifikan dengan nilai korelasi (r) yaitu 0,494 dengan kekuatan hubungan yang kuat dan bernilai positif yang artinya semakin tinggi konsumsi lemak semakin tinggi kadar $\mathrm{HbAlc}$ pada responden. Salah satu jenis asam lemak dapat berpengaruh pada metabolisme glukosa yang akan menyebabkan perubahan komposisi membran fosfolipid dan fungsi reseptor insulin. Konsumsi makanan tinggi lemak, akan mengubah keseimbangan energy. Asupan energi yang berlebihan akan meningkatkan resistensi insulin sekalipun belum terjadi kenaikan berat badan yang signifikan (27). Apabila kadar glukosa terjadi penurunan, maka cadangan glikogen yang berasal dari lemak atau protein akan diubah menjadi glukosa dan dilepaskan ke dalam darah sehingga terjadi hiperglikemia ${ }^{(28)}$. Diet tinggi lemak diketahui dapat memperburuk pengendalian kadar glukosa darah pada menderita diabetes melitus, lemak dapat memblokir kerja insulin, sehingga glukosa tidak dapat diangkut kedalam sel dan menumpuk dalam pembuluh darah, sehingga terjadi peningkatan kadar glukosa darah ${ }^{(15)}$. Diet rendah lemak dapat memperbaiki toleransi glukosa dan sensitivitas insulin apabila disertai dengan asupan karbohidrat kompleks dengan kandungan serat yang tinggi atau asupan tinggi protein $^{(29)}$.

Dari hasil wawancara responden mengonsumsi sumber serat yang terdiri dari sayur dan buah. Sayur yang sering dikonsumsi oleh responden yaitu ketimun, wortel, labu siam, sawi dan bayam. Sedangkan buah yang sering dikonsumsi oleh responden yaitu papaya, pisang dan melon. Berdasarkan hasil penelitian menunjukkan bahwa konsumsi serat terendah yaitu sebesar 8,56 gram serta yang tertinggi yaitu 39,8 gram. Terdapat hubungan yang signifikan antara konsumsi serat dan kadar HbA1c dengan nilai $(r)=-0,475$, kekuatan hubungan yang kuat dan bernilai positif yang artinya semakin tinggi konsumsi lemak semakin tinggi kadar $\mathrm{HbA} 1 \mathrm{c}$ pada responden. Hal ini di dukung dengan penelitian sebelumnya yang menyatakan bahwa apabila pasien DM tipe 2 melakukan diet serat tinggi secara rutin dan terkontrol maka kadar HbA1C akan mengalami penurunan sebesar $2,7 \%$ pada saat melakukan pemeriksaan selanjutnya ${ }^{(30)}$.

Sayur dan buah yang dikonsumsi oleh responden yang memiliki kadar $\mathrm{HbA1c}$ terkontrol atau mendekati normal, rata-rata tergolong dalam serat tidak larut, hemiselulosa ini tidak dapat dicerna enzim saluran pencernaan manusia dan bersifat menahan air. Pektin, gum, dan musilago mengandung derivate glaktosa yang menyerap air serta membentuk gel sehingga memperlambat waktu pengosongan lambung dan glukosa darah tidak cepat meningkat. Jenis serat yang larut dalam air dapat meningkatkan kekentalan isi di dalam usus halus, sehingga mengakibatkan penurunan aktivitas enzim amilase dan dapat memperlambat penyerapa glukosa (Setiawan, 2012). Kemudian secara tidak langsung dapat menurunkan kecepatan difusi pada permukaan mukosa usus halus sehingga mengakibatkan terjadinya penurunan kadar glukosa darah.

Keterbatasan penelitian ini yaitu peneliti tidak meneliti variabel-variabel yang juga dapat mempengaruhi kadar HbA1C seperti konsumsi obat-obatan dan asupan zat gizi mikro responden. Hasil penelitian ini dapat menjadi acuan dalam memberikan meal plan pada pasien DM tipe 2 yang dikaitkan dengan kondisi status gizi pasien.

\section{KESIMPULAN DAN SARAN}

Kesimpulan dari penelitian ini yaitu tidak ada hubungan yang signifikan antara status gizi dan kadar HbA1c pada responden. Ada hubungan yang signifikan antara konsumsi karbohidrat, lemak, dan serat dengan kadar HbA1c, tidak ada hubungan yang signifikan antara konsumsi protein dan kadar HbA1c pada responden. Diharapkan pada penelitian selanjutnya diberikan intervensi pada pasien DM dengan mengembangkan pangan fungsional yang mengandung serat yang tinggi. 


\section{DAFTAR PUSTAKA}

1. Soelistijo SA, Novida H, Rudijanto A, Soewondo P, Suastika K, Manaf A, et al. Konsensus pengelolaan dan pencegahan diabetes melitus tipe 2 di Indonesia 2015. Jakarta PB Perkeni. 2015;1-93.

2. Idris AM, Jafar N, Indriasari R. Pola Makan dengan Kadar Gula Darah Pasien DM Tipe 2. Media Kesehat Masy Indones. 2014;10(4):211-8.

3. Oguntibeju OO. Type 2 diabetes mellitus, oxidative stress and inflammation: examining the links. Int $\mathbf{J}$ Physiol Pathophysiol Pharmacol. 2019;11(3):45.

4. East M, Africa N. IDF diabetes atlas. Diabetes. 2017;20:79.

5. Dasar R. Laporan Hasil Riset Kesehatan Dasar (Riskesdas) Nasional 2007. Jakarta Badan Litbangkes, Depkes RI. 2018;

6. Depkes RI. Pharmaceutical care untuk penyakit diabetes mellitus. Jakarta Dep Kesehat Republik Indones. 2005;

7. Aamir AH, Ul-Haq Z, Mahar SA, Qureshi FM, Ahmad I, Jawa A, et al. Diabetes Prevalence Survey of Pakistan (DPS-PAK): prevalence of type 2 diabetes mellitus and prediabetes using HbAlc: a populationbased survey from Pakistan. BMJ Open. 2019;9(2):e025300.

8. Harna H, Irawan AMA, Swamilaksita PD, Sa'pang M. Perbedaan Durasi Tidur, Asupan Energi dan Zat Gizi Makro pada Anak Obesitas dan Non Obesitas. Jik (Jurnal Ilmu Kesehatan). 2021;5(1):155-60.

9. Sherwood L. Fisiologi manusia dari sel ke sistem. In EGC; 2001.

10. Zurita-Cruz JN, Manuel-Apolinar L, Arellano-Flores ML, Gutierrez-Gonzalez A, Najera-Ahumada AG, Cisneros-González $\mathrm{N}$. Health and quality of life outcomes impairment of quality of life in type 2 diabetes mellitus: a cross-sectional study. Health Qual Life Outcomes. 2018;16(1):17.

11. Yustiana E, Sumargi AM. Pengetahuan Mengenai Penanganan Penyakit Diabetes dengan Kepatuhan Melaksanakan Diet Diabetes pada Penderita Diabetes Mellitus Tipe 2. Exp J Psikol Indones. 2017;5(1):4553.

12. Putra IWA, Berawi K. Empat pilar penatalaksanaan pasien diabetes mellitus tipe 2. J Major. 2015;4(9):8-12.

13. McRae MP. Dietary fiber intake and type 2 diabetes mellitus: an umbrella review of meta-analyses. J Chiropr Med. 2018;17(1):44-53.

14. Nguyen NT, Nguyen X-MT, Lane J, Wang
P. Relationship between obesity and diabetes in a US adult population: findings from the National Health and Nutrition Examination Survey, 1999-2006. Obes Surg. 2011;21(3):351-5.

15. Tandra H. Segala sesuatu yang harus anda ketahui tentang diabetes. Gramedia Pustaka Utama; 2017.

16. Olczuk D, Priefer R. A history of continuous glucose monitors (CGMs) in selfmonitoring of diabetes mellitus. Diabetes Metab Syndr Clin Res Rev. 2018;12(2):181-7.

17. Sudoyo AW. Buku ajar ilmu penyakit dalam jilid II. 2009;

18. Sacerdote A, Dave P, Lokshin V, Bahtiyar G. Type 2 diabetes mellitus, insulin resistance, and vitamin D. Curr Diab Rep. 2019;19(10):1-12.

19. Utomo MRS, Wungouw H, Marunduh S. Kadar HbA1c Pada Pasien Diabetes Melitus Tipe 2 Di Puskesmas Bahu Kecamatan Malalayang Kota Manado. eBiomedik. 2015;3(1).

20. Permatasari SM, Sudargo T, Purnomo LB. Estimasi asupan indeks glikemik dan beban glikemik dengan kontrol gula darah pasien diabetes melitus tipe 2. J Gizi Klin Indones. 2015;12(2):45-53.

21. Almatsier S, Soetardjo S, Soekatri M. Gizi seimbang dalam daur kehidupan. 2019;

22. Biobaku F, Ghanim H, Batra M, Dandona P. Macronutrient-mediated inflammation and oxidative stress: relevance to insulin resistance, obesity, and atherogenesis. J Clin Endocrinol Metab. 2019;104(12):6118-28.

23. Wang L-L, Wang Q, Hong Y, Ojo O, Jiang $\mathrm{Q}$, Hou Y-Y, et al. The effect of lowcarbohydrate diet on glycemic control in patients with type 2 diabetes mellitus. Nutrients. 2018;10(6):661.

24. Tumiwa FA, Langi YA. Terapi gizi medis pada diabetes melitus. J BIOMEDIK JBM. 2010;2(2).

25. Harna H, Kusharto CM, Roosita K. Intervensi Susu Tinggi Protein Terhadap Tingkat Konsumsi Zat Gizi Makro Dan Status Gizi Pada Kelompok Usia Dewasa. Media Kesehat Masy Indones. 2017;13(4):354.

26. Ke Q, Chen C, He F, Ye Y, Bai X, Cai L, et al. Association between dietary protein intake and type 2 diabetes varies by dietary pattern. Diabetol Metab Syndr. 2018;10(1):1-10.

27. Azrimaidaliza A. Asupan Zat Gizi dan Penyakit Diabetes Mellitus. J Kesehat Masy Andalas. 2011;6(1):36-41.

28. Suriani N. Gangguan Metabolisme Karbohidrat pada Diabetes Melitus. Malang 
Pascasarj Ilmu Biomedik Fak Kedokt Univ Brawijaya. 2012;

29. Astuti CM, Setiarini A. Faktor-faktor yang berhubungan dengan pengendalian kadar glukosa darah pasien diabetes melitus tipe 2 rawat jalan di poliklinik penyakit dalam RSJ Prof. Dr Soerojo Magelang Tahun. 2013;2013.

30. Nadimin, Ayu Dara S, Sadariah. Pengaruh Pemberian Diit Dm Tinggi Serat Terhadap Penurunan Kadar Gula Darah Pasien Dm Tipe-2 Di Rsud Salewangang Kab. Maros. Media Gizi Pangan. 2009;1:29-34. 